\title{
FILANTROCAPITALISMO VERSUS FILANTROPIA PARA A JUSTIÇA SOCIAL: UM DEBATE NORTE-AMERICANO SOBRE COMO LIDAR COM A POBREZA ${ }^{1}$
}

\author{
Patricia Kunrath Silva ${ }^{1}$ e Ruben George Oliven ${ }^{2}$ \\ ${ }^{1}$ Escola Superior de Marketing e Propaganda, Porto Alegre, RS, Brasil \\ ${ }^{2}$ Universidade Federal do Rio Grande do Sul, Porto Alegre, RS, Brasil
}

A ética do trabalho e o ganho financeiro como recompensa decorrente dela tem sido central no imaginário norte-americano (Oliven 2001). A ideia de uma sociedade democrática, livre das amarras feudais que imperavam na Europa e aberta aos imigrantes sempre foi uma pedra de toque do ideário dos Estados Unidos. Ganhar dinheiro e fazer fortuna são vistos como marcas dos que são bem-sucedidos. Ser um winner é uma das metas que a sociedade e a escola apregoam. Mas o que fazer com os que não conseguem enriquecer e se tornam losers? São eles culpados de sua situação ou merecem alguma forma de ajuda que alivie seu sofrimento? A filantropia tem um papel central nessa questão.

A filantropia norte-americana movimenta altas cifras de dinheiro, emprega profissionais especializados e promove cursos e eventos. Pequenas organizações não-governamentais, ativistas e movimentos sociais competem com fundações criadas por bilionários por recursos. É interessante ver que esses atores tentam captar inclusive as pequenas doações individuais de trabalhadores e jovens que se sentem atraídos pela ideia de contribuírem para um mundo melhor e terem impacto social. Trata-se de um vasto mercado que se conecta com outros países, formando redes e ligando atores do terceiro setor ao setor privado e aos governos e alinhando-os a agências multilaterais como a Organização das Nações Unidas e o Banco Mundial.

Nesse campo de disputas, há uma série de indicadores que medem as doações filantrópicas e estabelecem rankings. O World Giving Index é 
um relatório anual da Charities Aid Foundation que analisa as tendências mundiais de doação e classifica países de todo mundo em relação à doação de dinheiro, tempo e ajuda a estranhos. A Charity Navigator e a Charity Watch são organizações não-governamentais que fornecem informações sobre a qualidade da filantropia praticada por diferentes organizações. Já a America's Top Givers é um ranking publicado anualmente pela Forbes, revista sobre assuntos econômicos e financeiros.

Mas, do que exatamente estamos falando ao tratar de filantropia? Ela pode se referir a pequenas doações individuais feitas para o bem de outrem, ou à transferência de bilhões de dólares de magnatas para suas fundações familiares ou organizações parceiras. Independentemente do extremo em que se encontrar, a filantropia tende a se caracterizar como a doação de algo privado - dinheiro, tempo, contatos - para o bem público. Para Witkowski e Bauerkämper

(...) a filantropia é a doação de tempo individual ou dinheiro privado, sem compulsão, para benefício daqueles que estão fora da família, destinados a fazer melhorias na sociedade. Embora às vezes sejam difíceis de se separar do comportamento auto interessado, dos interesses pessoais e do lobby, as ações filantrópicas têm a intenção de melhorar o bem-estar dos seres humanos, aliviar a miséria ou melhorar a qualidade de vida por meio de atos pessoais de apoio. A filantropia compreende uma ampla gama de atividades, que vão desde doações individuais e coletas até fundações institucionalizadas. Quer se trate de obrigações comuns que criam um sentimento de pertença ou de laços comuns que formam a base da democracia, a doação individual de tempo e valores tem desempenhado um papel importante, não só na criação de relações interpessoais, mas também na formação de conexões societais. Desta forma, a filantropia relaciona-se estreitamente com o desenvolvimento de laços independentes que se tornam um baluarte para a sociedade civil. Em nível normativo, além disso, as atividades filantrópicas cumprem valores cruciais da sociedade civil: empatia, tolerância, apreciação do outro e envolvimento com questões sociais. No entanto, as investigações empíricas demonstraram que as normas de civilidade vão de mãos dadas com a busca de interesse e objetivos particulares. Como a sociedade civil, a filantropia é um termo e conceito multifacetado, ambivalente e até ambíguo (Witkowsky e Bauerkämper, 2016: 3).

Com suas festas de gala, banquetes de fundraising, conferências de pares e dinâmicas de alianças, a filantropia é comumente realizada em nome de famílias de projeção como o casal Bill e Melinda Gates. Como um contraponto à lógica individualista, expressa no ideário norte-americano do self-made man, a prática filantrópica seria um momento de 
reconhecimento do pertencimento desse indivíduo e sua família - já que ela é frequentemente realizada em nome de casais proeminentes - a uma sociedade maior, que possibilitou o enriquecimento e que agora deve receber sua retribuição.

Esse retorno pode ser feito de distintas formas para instituições e grupos próximos ou distantes de seus benfeitores, mas nossos interlocutores parecem concordar que a filantropia seria a sua forma de participação democrática. Eles argumentam que, em lugar de pagar impostos a um Estado que passará a reger seus recursos, preferem destinar a verba por meio de doações a suas causas eleitas. Dessa forma, a filantropia aparece como uma resposta ao que consideram a ineficácia da ação estatal e constitui a forma escolhida por esses atores para tratar da pobreza e da governança de populações.

Se, etimologicamente, filantropia significa amor à humanidade, sua prática nunca foi uma tarefa simples. Por isso, seu universo é controverso e há diferentes narrativas sobre sua prática. A razão iluminista ocupou um papel central na modificação do conceito, em um esforço da separação do ato afetivo caritativo e da prática estruturada e planejada da filantropia.

As doações eram tradicionalmente caracterizadas como uma forma piedosa de ajuda ao próximo. O termo que se aplica a essa prática é caridade. Através dela, a dádiva era vista sob o prisma da moral cristã na qual existe a valorização da pobreza como redentora dos pecados. Já a filantropia moderna muitas vezes é apresentada como uma prática científica e racional e como um dos pilares do projeto iluminista. Discutindo a diferença ente caridade e filantropia, Sanglard argumenta que

a primeira, por ser obra piedosa, pressupõe a abdicação de toda a vaidade de seu autor e propugna o anonimato, ao passo que a segunda é marcada por um gesto de utilidade, e neste caso a publicidade se torna uma arma importante nas mãos dos filantropos, além de acirrar-lhes a rivalidade (...) A filantropia pode ser entendida, grosso modo, como a laicização da caridade cristã, ocorrida a partir do século XVIII, e que teve nos filósofos das luzes seus maiores propagandistas. O fazer o bem, o socorro aos necessitados, deixa de ser uma virtude cristã para ser uma virtude social; e a generosidade é entendida pelos filósofos ilustrados como a virtude do homem bem-nascido, que tem inclinação para doar, doar largamente, daí a forte presença das grandes fortunas entre os principais filantropos (Sanglard, 2005: 30).

Nessa perspectiva, filantropia e caridade são contrapostas: apela-se para a prática filantrópica otimizada e estratégica e para que se pare de fazer caridade, apresentando esta última com uma carga pejorativa. Sanglard (2005) aponta ainda o caráter laico que se pretende dar à filantropia, em oposição 
à caridade ligada ao ethos cristão. Mas não se deve ver os termos caridade e filantropia como antagônicos. A religião não está ausente na filantropia. Por exemplo, nos Estados Unidos, os fundamentos cristãos desta podem ser detectados na ética protestante que lhe é subjacente (Weber 1970).

A filantropia também surge como forma de lidar com conflitos sociais das modernas sociedades de classes. Para Witkowski e Bauerkämper (2016: 3):

(...) a filantropia torna-se um espaço contestado onde os valores do doador e do recipiente estão envolvidos. Desta forma, é uma "guerra civil por outros meios" na medida em que os doadores apresentam visões concorrentes para a sociedade (...). De fato, a mudança de uma ênfase na doação de caridade a fim de aliviar as necessidades básicas para a filantropia científica com o intuito de atacar problemas no seu núcleo, um processo que começou com o Iluminismo, quase assegurou que a doação filantrópica fosse mais do que o altruísmo, conforme cada doador procurava encontrar soluções para problemas sociais.

A "filantropia científica" que surgiu no início do século XX visava prevenir a ocorrência de problemas sociais ou a resolução de problemas preexistentes (Witkowski e Bauerkämper 2016: 3).

\section{II}

O Ensaio sobre a Dádiva de Marcel Mauss (2003), publicado originalmente em 1923-24, é frequentemente tomado como inspiração para analisar trocas. Seu conceito de dádiva é complexo e vários cientistas sociais se debruçaram sobre ele, procurando decifrar seus significados. A tríade dar, receber e retribuir é considerada por muitos a pedra basilar do estabelecimento de relações sociais. Os contemporâneos de Mauss tendiam a enfatizar as dimensões da dádiva relacionadas à lei, às obrigações e às prestações totais. Nesse sentido, Hart assinala que Mauss "raramente se refere a esse processo de dar e retribuir como sendo 'reciprocidade'" (Hart 1999: 481). Entretanto, a partir dos anos 1960, surgiu uma posição consensual de que o Ensaio sobre o Dádiva "continha uma teoria de troca que tomava a identificação entre a coisa dada e o espírito do doador como o princípio explicativo de transações. Desde então esta tese ganhou força e acabou por se consolidar (...)" (Sigaud 1999: 89). Sigaud argumenta que isso se deveu principalmente à famosa introdução de Lévi-Strauss (1983) à antologia dos escritos de Mauss em que aquele desviou o sentido dos escritos deste último em direção a sua própria teoria de reciprocidade, privilegiando a troca econômica no lugar dos propósitos do autor do Ensaio sobre a Dádiva. 
Ao analisar estudos sobre sociedades tradicionais do noroeste americano, Mauss usou o termo nativo potlatch, que significa "nutrir, consumir" para ritos, que compreendem trocas com rivalidade agonística em que chefes das tribos distribuem e destroem suas riquezas. O potlatch é frequentemente visto como um ritual em que os nobres competem entre si como forma de manutenção do poder e reconhecimento social. Mas, para Mauss ele não é apenas um momento paradigmático da troca e destruição de riquezas, mas uma ampla estrutura de reciprocidade entre coletividades, que inclui as relações com os ancestrais. Mais do que um ritual, o potlatch é entendido ainda como uma forma arcaica de contrato, no intuito de demonstrar a inexistência mesmo nas sociedades ditas primitivas de uma economia natural. Ele aparece sob forma articulada como um sistema de prestações coletivas, pois como argumenta Mauss, não são indivíduos que trocam, mas sim "pessoas morais" como clãs, tribos e famílias em grupos e/ou representadas por seus chefes. Assim, o potlatch faz circular mais que bens e mercadorias:

"São, antes de tudo, amabilidades, banquetes, ritos, serviços militares, mulheres, crianças, danças, festas, feiras, dos quais o mercado é apenas um dos momentos e nos quais a circulação de riquezas não é senão um dos termos de um contrato bem mais geral e bem mais permanente. Enfim, essas prestações e contraprestações se estabelecem de uma forma sobretudo voluntária, por meio de regalos, presentes, embora elas sejam no fundo rigorosamente obrigatórias, sob pena de guerra privada ou pública. Propusemos chamar tudo isso o sistema das prestações totais. (Mauss, 2003: 191).

Como salienta Parry, "As pessoas que executam as trocas que interessam centralmente a Mauss o fazem incumbidos de posições de status e não atuam em seu próprio proveito. As pessoas tampouco estão em oposição" (Parry 1986: 476). Referindo-se ao interesse ou desinteresse das dádivas, Parry assinala que "Mauss repetidamente enfatiza a combinação de interesse e desinteresse, de liberdade e constrangimento, na dádiva. O 'interesse' tampouco poderia possivelmente ser uma questão de auto (no sentido de individual)-interesse" (Parry 1986: 476). Esse autor critica a atribuição à Mauss, por parte de vários autores, da impossibilidade de uma dádiva gratuita. A leitura destorcida de que ninguém faz nada sem esperar um retorno estaria demonstrando como nós concebemos que a dádiva deveria ser, por colocá-la em oposição às transações de mercado nas sociedades complexas e segmentadas:

Portanto, enquanto Mauss é geralmente representado como nos dizendo como de fato a dádiva nunca é gratuita, o que eu creio que ele realmente está nos dizendo é como nós adquirimos uma teoria de que ela deveria sê-lo. Tanto a troca interessada quanto o presente desinteressado emergem como dois lados 
da mesma moeda. Dado um profundo desgosto pela primeira, a desconfiança do segundo é lógica. O presente não reciprocado degrada o recipiente e a caridade do "rico que distribui esmolas" é condenada - presumivelmente porque nega a obrigação e substitui a interdependência recíproca na qual a sociedade é fundada por uma dependência assimétrica (Parry 1986: 459).

Apesar da complexidade do Ensaio sobre a Dádiva (Laidlaw 2000, Venkatesan 2011, Pipyrou 2014, Sanchez 2017, Carrier 2017, Gregory 2017, Laidlaw 2017, Strathern 2017, Yan 2017, Parry 2017), é frequente a análise da moderna filantropia das elites como uma espécie de potlatch contemporâneo. Assim, por exemplo, em seu texto "A Filantropia Moderna à Luz de Mauss", a socióloga Ilana Silber, integrante do M.A.U.S.S (Movimento Anti-utilitarista nas Ciências Sociais) argumenta que

(...) o dom filantrópico moderno não é menos um fenômeno total que a troca de presentes arcaica, que ele alia às mesmas dimensões econômicas, legais, estéticas, morais e mesmo religiosas e se acompanha muitas vezes, à semelhança das trocas arcaicas estudadas por Mauss, de ritos, de festas e de celebrações: cerimônias de inauguração, jantares, galas, encontros, concertos onde artistas e outras personalidades brilhantes contribuem para aumentar a efervescência social, para empregar o vocabulário de Durkheim (Silber 2008: 7).

Essa autora assinala a importância dessa doação, o paradoxo do caráter dadivoso, ao mesmo tempo obrigatório e espontâneo, interessado e desinteressado, especialmente no que tange ao exercício de afirmação das identidades dos doadores. Para ela, a filantropia moderna é uma expressão da identidade norte-americana, tendo um importante papel na construção de laços sociais entre pares e na supressão de conflitos:

Se é inegável que a dádiva moderna apresenta uma característica cada vez mais impessoal, anônima e burocrática, não é menos verdade que a filantropia guarda um conteúdo pessoal muito importante, e inclusive que o vínculo entre a dádiva e a identidade do doador subsiste nela. Parte dessa persistência tem a ver com a simples realidade da coleta de fundos, muitas das quais se fazem através de redes de relações informais muito eficazes. Na realidade, frequentemente, os ricos doam depois de ter sido pessoalmente solicitados por uma pessoa próxima: colega, sócio de negócios ou mesmo amigo (Silber 2008: 7).

Em sua crítica à ação filantrópica, Hanson também recorre à teoria da dádiva para analisar a filantropia contemporânea e afirma que:

A caridade moderna da elite é centrada na classe e excludente, empregando rituais de trocas caritativas, como o primitivo potlatch, para perdas e trocas es- 
truturadas, ambas afirmando e ocultando status e poder, ofuscando e ao mesmo tempo iluminando privilégios. Modelos tradicionais de doações de caridade são frequentemente eurocêntricos e monoculturais, empregando uma "teoria de troca" baseada no modelo de mercado, assumindo que doar é uma série de "compras" diádicas e reciprocadas feitas por doadores que buscam a utilidade máxima. Olhando para a moderna doação de caridade como um "fato social total" (Mauss), podemos detectar padrões subjacentes às doações de caridade de elite que fazem da aparente renúncia à riqueza uma declaração de poder. As organizações sem fins lucrativos estão inseridas nessas dinâmicas, na medida que a economia de dádiva das elites se expressa através da doação caritativa moderna (Hanson, 2015: 2).

É tentador ver no potlatch e no "sistema de prestações totais" descritos por Mauss uma chave de leitura para o universo filantrópico contemporâneo protagonizado por institutos e fundações norte-americanas. Essa leitura é, entretanto, problemática porque procura aplicar a lógica de sociedades arcaicas a sociedades complexas, equiparando processos que podem ter significados diferentes, o que não decorre automaticamente da obra de Mauss. A filantropia norte-americana tem lugar num contexto muito diferente das sociedades descritas por ele e a transposição automática pressupõe que uma sociedade complexa não passa de uma sociedade simples que se complexificou. Há obviamente diferenças de escala e de tempos históricos que precisam ser levadas em consideração para evitar uma análise anacrônica. Ao passo que o potlatch é um ritual que se dá em sociedades que Mauss chamou de arcaicas nas quais os nobres competem entre si como forma de manutenção do poder e reconhecimento social, as dádivas da filantropia norte-americana ocorrem em uma sociedade de classes que produz muita riqueza que é distribuída de forma bastante desigual. A questão que a filantropia procura equacionar é como os ricos podem ajudar a atenuar a pobreza. Embora haja busca de prestígio entre os filantropos, suas doações não apresentam a competição agonística do potlatch analisada na obra de Mauss.

\section{III}

São duas as grandes vertentes da filantropia norte-americana contemporânea: o filantrocapitalismo (também chamado de nova filantropia ou filantropia estratégica) e a filantropia progressista ou de justiça social. A seguir examinaremos os dois modelos e apresentaremos entrevistas com representantes deles. 


\section{Filantrocapitalismo}

Em 2006, a revista The Economist publicou um artigo intitulado "The birth of philanthrocapitalism. The leading new philanthropists see themselves as social investors" ("O nascimento do Filantrocapitalismo. Os novos filantropos líderes se veem como investidores sociais") em que já se anunciava a tendência da filantropia como investimento social, desenvolvida na intersecção dos setores privado e terceiro setor:

A necessidade de a filantropia se tornar mais parecida com os mercados de capitais com fins lucrativos é um tema comum entre os novos filantropos, especialmente aqueles que fizeram suas fortunas nas finanças. Do modo que eles veem a questão, três coisas são necessárias para que um mercado filantrópico desse tipo funcione. Primeiro, precisa existir algo no qual os filantropos possam "investir" - algo que, idealmente, vai ser criado por "empreendedores sociais", exatamente do mesmo modo como no mundo para fins lucrativos empreendedores criam companhias que acabam sendo negociadas na bolsa de valores. Segundo, o mercado requer uma infraestrutura, o equivalente filantrópico do mercado de ações, bancos de investimentos, centros de pesquisa, consultores de administração, e assim por diante (...) Terceiro, os próprios filantropos precisam se comportar mais como investidores (The Economist 2006: 9).

Alguns livros publicados em 2008, no auge da crise financeira internacional, discutem o filantrocapitalismo como uma nova abordagem no universo filantrópico. Um deles, intitulado Philanthrocapitalism. How the rich can save the world (Filantrocapitalismo. Como os ricos podem salvar o mundo), foi escrito pelo jornalista Matthew Bishop e pelo autodenominado "especialista em progresso social" Michael Green. De acordo com o prefácio do livro, este trata do

(...) renascimento da doação e da filantropia, liderado pelos criadores de riqueza mais bem-sucedidos do mundo. Filantrocapitalismo descreve como eles doam, ao aplicarem técnicas e modos de pensar do mundo dos negócios a sua filantropia. Também descreve o crescente reconhecimento de líderes do capitalismo de que devolver muito de sua fortuna para melhorar a sociedade é tão parte do sistema quanto fazer dinheiro (Bishop \& Green 2008: 8).

Outro livro sobre o tema, intitulado Just Another Emperor? The myths and realities of Philanthropcapitalism (Outro Imperador? Os mitos e as realidades do Filantrocapitalismo) foi escrito por Michael Edwards (2008), que trabalhou em posições administrativas sênior na Oxfam, Voluntary Services Overseas, Banco Mundial e Ford Foundation. Segundo o autor, "Um novo movimento 
está surgindo, prometendo salvar o mundo ao revolucionar a filantropia, fazendo organizações sem fins lucrativos operarem como empresas e criando novos mercados para bens e serviços que beneficiam a sociedade".

Um dos nomes mais emblemáticos da vertente filantrocapitalista é o de Bill Gates. O criador da Microsoft, ao lado de sua esposa Melinda Gates que também empresta seu nome à fundação do casal, é responsável pela doação - ou investimento, como prefere a linguagem crescente no meio de filantropos - de bilhões de dólares nos Estados Unidos e ao redor do globo. Em 2017, Gates fez a maior doação de sua fortuna desde o ano 2000, tendo transferido 64 milhões de ações da Microsoft, no valor de 4,6 bilhões de dólares, para a sua própria Fundação. ${ }^{2}$

Bill e Melinda Gates são os criadores do programa "The Giving Pledge" (“A Promessa de Doar"), através do qual pessoas com patrimônio igual ou superior a um bilhão de dólares se comprometem a investir metade de suas fortunas em causas sociais ao longo de suas vidas. Em 2010, 40 bilionários aderiram à campanha do casal Gates, entre eles Michael Bloomberg e Ted Turner. Um dos grandes doadores que fazem parte do "The Giving Pledge" é o megainvestidor Warren Buffet. No ano de 2014, ele foi considerado o "homem mais generoso do mundo", tendo doado 2,1 bilhões de dólares para a Fundação Bill e Melinda Gates.

Em sua carta ao programa, Bill e Melinda afirmaram

Nós fomos abençoados com boa fortuna além das nossas mais ousadas expectativas, e somos profundamente gratos. Mas assim como estes presentes são grandiosos, também sentimos uma grande responsabilidade em usá-los bem. É por isso que estamos tão felizes em fazer um comprometimento explícito à Giving Pledge ${ }^{3}$.

A declaração do casal evidencia a concepção dos filantropos norte-americanos do "give back", ou seja, da retribuição. Nessa perspectiva, a fortuna gerada seria fruto de uma benção divina - como aponta Robert Bremner (1960) em sua obra sobre a filantropia americana- e/ou fruto da sociedade que ofereceu a oportunidade de sua conquista.

Esse tipo de filantropia tem os seus apóstolos e os seus detratores. Seus admiradores descrevem o filantrocapitalismo como um antídoto à morosidade da máquina burocrática do Estado em atender às necessidades sociais dos mais necessitados. Eles argumentam que o mercado ainda é o melhor mecanismo para regular a sociedade e que é preciso adotar métodos empresariais para desenvolver programas filantrópicos. Do mesmo modo, fazem uma apologia do lucro como o que move as pessoas e as instituições. Logo, mercado e filantropia, longe de serem opostos, podem operar juntos. 
A crítica à burocracia e aos processos governamentais e de agências multilaterais aparece repetidamente como justificativa para o fomento do setor filantrópico. No universo do filantrocapitalismo, o discurso que emerge e tenta se estabelecer como hegemônico é o do business. Utilizam-se jargões como estratégia, orientação de mercado e medição de impacto. Os atores desse campo procuram se distanciar de modelos de caridade que consideram paliativos e declaram buscar soluções efetivas para os problemas sociais.

O medo de conflitos e a desestruturação de um sistema que produz muitas desigualdades também aparecem como molas propulsoras da filantropia contemporânea:

Governos tanto da direita como da esquerda parecem cada vez mais interessados que indivíduos ricos lhe deem uma mão. Mesmo assim, se os ricos não assumirem essa responsabilidade, eles arriscam provocar uma repercussão no público contrária ao sistema econômico que permitiu se tornarem tão ricos. (Bishop e Green, 2008: 35).

Dessa forma, aparecem duas formas de intervenção social vistas como concorrentes por uns e como complementares por outros: a concessão de direitos, a partir da ótica do Estado - e se é de direito da população é, por sua vez, dever dos governos atendê-los - e as doações privadas, muitas vezes mal vistas porque não entendidas dentro de uma lógica redistributiva de obrigação e direitos, mas como geradores de ainda mais crédito por parte de seus prestadores. Mas e se a doação de recursos fosse vista como uma obrigação imposta às elites?

Os críticos do filantrocapitalismo argumentam que ele representa um jogo de interesses que nada mais faz do que procurar, através das doações, obter isenções fiscais para os mais ricos. Como indica Adloff (2016: 49), as "fundações são criadas em tempos em que oportunidades para moldar a sociedade estão abertas às elites filantrópicas - por exemplo, especialmente em situações históricas quando o Estado dá a essas elites escopo para ação". Desde a crise financeira internacional de 2008, observa-se uma crescente promoção das práticas chamadas filantrocapitalistas, ou seja, que definem o capitalismo como o melhor sistema social já elaborado, porém sujeito a falhas que ele mesmo iria consertando por meio de ações sociais centradas em lógicas de mercado.

Para esse autor, as elites sempre operaram de forma muito próxima ao Estado, embora o discurso oficial frequentemente não seja esse. Essa proximidade aparece desde o pioneirismo na implementação de projetos que depois seriam coordenados com as autoridades até a capacidade consultiva. Essas elites clamam ainda por um papel de liderança na sociedade, sendo, 
por um lado, liberadas de obrigações sociais institucionalmente reguladas e impostas pelo Estado e, por outro assumindo "compromissos voluntários na forma de cidadania corporativa e da criação de fundações":

Aqueles que provavelmente criarão fundações constituem um subgrupo entre os membros ricos da sociedade, ou seja, aqueles que visam exercer influência na sociedade e um certo grau de controle sobre os fundos doados. Isso combina o individualismo com um interesse no bem comum. As fundações e outras formas de filantropia podem permitir que as elites econômicas criem uma ponte entre elas e os setores político, social, religioso, científico e outros a fim de exercer influência nesses campos. Através de atividades filantrópicas, alguém que ocupa uma posição de elite econômica também pode pertencer à elite do "bem comum". As elites, portanto, não só criam fundações, mas as fundações também criam elites - elites do "bem comum". Como já vimos, essas elites podem competir com o Estado ou cooperar com ele, e seu compromisso pode implicar formas de dar baseadas em solidariedade ou hierarquia. Isso varia de acordo com os contextos sociais, culturais e históricos (Adloff 2016: 51).

A filantropia aparece como um dispositivo moral que, como indica Odendahl (1990), responde por vezes ao medo das elites de perderem seus privilégios por meio da cobrança de impostos ou mesmo de uma revolta ou revolução das classes mais baixas. O medo de conflitos e a desestruturação de um sistema injusto também aparecem como molas propulsoras do filantrocapitalismo. Maurer (2015) assinala que a criação de filantropias em paraísos fiscais ou para tirar vantagem da legislação sobre impostos ajuda a compreender como dinheiro e moralidade andam juntos. Para ele, as concessões da legislação tributária norte-americana para a filantropia ${ }^{4}$, uma concessão no coração do capitalismo, demonstraria que sabemos haver algo de errado com o dinheiro e por isso há a necessidade de purificá-lo. Como indica Parry, referindo-se às dádivas na Índia: "a dádiva incorpora os pecados do doador, a quem ela livra do mal pela transferência ao recipiente do fardo perigoso e degradante da morte e da impureza" (Parry 1986: 459).

É possível argumentar que, mais que um problema com o dinheiro em si, o que é aliviado por meio desse tipo de filantropia é o mal-estar causado pela concentração de renda e a crescente desigualdade. Nesse sentido, Bishop e Green deixam transparecer o medo da insustentabilidade do sistema econômico atual e a consequente transição para modelos alternativos:

Descobrir exatamente que papel desempenhar no sistema de governança global também colocará desafios significativos, particularmente se a fundação desempenha crescentemente um papel formal nela, baseada no modelo pioneiro do 
Global Fund, do qual a Fundação Gates faz parte da diretoria ao lado de governos soberanos. A governança do fundo foi desenhada para abordar algumas das deficiências da abordagem tradicional das Nações Unidas, que frequentemente é burocrática e lenta". (Bishop \& Green, 2008: 149).

O Global Philantrophy Forum (GPF), organização guarda-chuva que é espaço de debates e trocas de conhecimento sobre o filantrocapitalismo ${ }^{5}$, é uma iniciativa do World Affairs Council ${ }^{6}$, instituição criada em 1948 em San Francisco para pensar questões mundiais como migração, conflitos e pobreza. Ela é baseada na crença de que as soluções para os problemas mais candentes do mundo são encontradas quando os setores privado, filantrópico e público trabalham em conjunto. O GPF foi criado em 2001 para ser uma rede de grandes filantropos e investidores sociais e atua em cerca de cem países e tem afiliados na América Latina, África e Ásia. ${ }^{7}$ Seu objetivo é construir uma comunidade de filantropos e fortalecer a natureza estratégica da doação e investimento social de seus membros.

Jennifer ${ }^{8}$, uma das diretoras do Global Philanthropy Forum, é uma atora representativa da lógica do filantrocapitalismo. Quando a entrevistamos na sede da organização em San Francisco, California, ela começou contando que se interessava por filantropia há bastante tempo, mas que foi "meio que por acidente" que foi trabalhar na área:

Eu me interessava por desenvolvimento, o que a filantropia poderia fazer que outros setores não podem e como a filantropia poderia ajudar governos fracos dando suporte social à sociedade civil. Pensava no que faltava nos governos e no setor privado. Meu interesse em desenvolvimento me levou à filantropia.

Jennifer demonstrou incômodo quando nos referimos à filantropia como um mercado, rebatendo que o correto seria setor. Ela prosseguiu explicando que a filantropia nos Estados Unidos é muito dinâmica e representaria uma porcentagem significativa do produto interno bruto. Além disso, apontou a transição pela qual o setor estaria passando e indicou que:

O marco legal permite aos doadores fazerem o que querem fazer, é flexível. Há muita gente no setor, há setor de negócios, o setor social, administração e consultoria e como há muitas ferramentas tecnológicas, então há muitas inovações. A forma como o dinheiro circula no setor dá meios para ele se reinventar, reinventar suas estratégias e práticas.

A preocupação com quem irá receber o dinheiro e como este será usado estava visivelmente marcada na sua fala. Para ela, assim como para a rede de filantropos que representa, é preciso ter critérios rígidos na hora 
de selecionar essas pessoas ou grupos beneficiários, deixar claro com que finalidade o dinheiro está sendo doado ou investido e o que se quer ver realizado: "você tem que conhecer muito bem para quem está doando". Sobre a diferença entre caridade e filantropia, Jennifer explicou:

Caridade é quando você vê o sintoma de um problema e trabalha nele. Como, por exemplo, quando você vê um casal desempregado vivendo uma vida dura, com filhos, e você compra comida e leite para eles. Mas esses pais podem não ter estudado. Para encontrar uma solução, você tem que investir antes que vire um problema. Você trabalha nas raízes das causas. Isto é quando você está fazendo filantropia. Nós precisamos que os empreendedores criem empregos, nós precisamos de infraestrutura para economizar energia. Nós precisamos investir na estrutura do sistema para ter um melhor ambiente, melhor nutrição e, consequentemente, melhores crianças. O que faz mais sentido para mim é investir para fazer uma mudança nas raízes [dos problemas]. Caridade é mais assistência humanitária, mas você não trabalha em uma solução de longo prazo. Ambas são necessárias.

A narrativa de Jennifer é fortemente marcada pela ideia de que os Estados Unidos foram moldados pelos valores trazidos pelos imigrantes protestantes ingleses, o que seria responsável pela disseminação da filantropia enquanto um valor ético na cultura do país. Para o protestantismo, fazer dinheiro não cria culpa, mas responsabilidade. A possibilidade de enriquecer e de que haja uma classe abastada aparece como condição sine qua non para a prática filantrópica, ou seja, só existe filantropia porque se permite existir tanta desigualdade:

Deus te concedeu bênçãos e uma delas é financeira. Por meio do trabalho árduo você fez dinheiro. Até o final da Primeira Guerra Mundial não havia imposto de renda, mas as pessoas doavam porque elas acreditavam nas oportunidades do país. As pessoas vinham [para os Estados Unidos] e tinham em suas mentes a imagem de pessoas que vieram e fizeram sucesso. Então quando você alcança, você quer retribuir e isso moldou o papel da filantropia nos Estados Unidos. O conceito de governo no país é que é melhor quando o governo faz o mínimo. As pessoas querem fazer o que precisam para ter sucesso. O voluntariado é forte, apesar do papel do governo ter aumentado no século XX. Antes éramos moldados pela ideia de um governo mínimo. O governo na Europa tem um papel maior. O engajamento individual e o voluntariado são influências da cultura ou ética protestante. O país foi construído com oportunidades, então as pessoas querem dar algo em troca. 
Na sequência, a conversa voltou-se para a relação das pessoas com o dinheiro no país. Ela explicou que:

Há uma tradição nos Estados Unidos das pessoas fazerem dinheiro enquanto empreendedores. É uma parte da nossa mitologia, nosso mito. Se você fez muito dinheiro é resultado de trabalho árduo (pago com muito tempo e sacrifício da sua vida privada). Dessa forma, seria "natural pensar que se você conseguiu então outros também podem. Os seus filhos deveriam fazer o mesmo e é natural pensar isso nos Estados Unidos, porque o país segue oferecendo oportunidades".

Apesar da chamada "crise do sonho norte-americano", marcada pelo crescimento da desigualdade de renda e o aumento da pobreza (Putnam 2016), para a entrevistada a ideia de oportunidades é central para o sucesso:

As crianças precisam ter oportunidade de ter uma vida cheia de sentido. Precisam poder trabalhar e fazer algo que tenha significado, não podemos apenas distribuir dinheiro. Se você se sai bem é por meio do trabalho duro e compaixão. O dinheiro é um subproduto, e não um fim em si mesmo. Nesse contexto, se você está fazendo a diferença, causando impacto, contribuindo para algo maior que você mesmo, você pensa sobre o sentido da sua vida. Doar dinheiro é então uma grande parte desse legado, de um continuum de uma vida significativa. É preciso ter então senso de responsabilidade, boas oportunidades e o senso de retribuição por meio da doação. Quanto a noções de pobreza, isso tem a ver com um pensamento político. Algumas pessoas pensam que trabalharam duro e não tiveram oportunidades e que se tivessem oportunidades iriam se sair bem. É uma questão política para além dos filantropos. Aqui nos Estados Unidos não há nenhuma lei que diga que se deve deixar dinheiro para seus filhos, como em alguns outros países. Aqui os pais só deixam se assim o escolherem.

Presente na fala de Jennifer está o fato de que, diferentemente do Brasil, no qual os filhos são legalmente "herdeiros necessários" dos bens dos pais, nos Estados Unidos não há obrigatoriedade de testar bens para os filhos. Isso significa que as pessoas podem decidir deixar em testamento boa parte de seu patrimônio para organizações ou causas com as quais simpatizam.

Perguntada sobre as diferentes práticas do setor, como Responsabilidade Social Corporativa, Investimento Social Privado, Voluntariado e Filantropia Estratégica, Jennifer identificou Investimento Social Privado como uma terminologia brasileira, acrescentando que nos Estados Unidos haveria empresas sociais, isto é, novos modelos de negócios que buscam conjugar o impacto social à geração de lucro e cuja organização pode variar do modelo privado ao Terceiro Setor. Para ela, todos esses termos viriam sob o guarda-chuva da filantropia estratégica: 
O escopo do que chamamos filantropia é cada vez mais amplo. Responsabilidade Social Corporativa é algo a se definir: se dizíamos que as companhias se tornavam cidadãs, então agora vemos os negócios centrais das companhias voltando a atenção para melhores práticas. Ser uma corporação cidadã e fazer o bem é mais importante do que definir o que é filantropia. As linhas estão cada vez mais borradas e isto é um fato mesmo para a filantropia individual: pode ser empréstimos, por exemplo. Há uma grande mistura no que as pessoas estão definindo como filantropia. O conceito de cidadania se infiltra fortemente aqui, na consciência dos norte-americanos, baseada no indivíduo. Existem direitos e existem responsabilidades. O que eu consigo correlacionar mais é a ideia de individualismo. O país foi construído por indivíduos rompendo limites. Você só pode confiar em si mesmo. Você ascende ou cai baseado em si mesmo, não importa de qual comunidade venha. Se o indivíduo é tão forte assim, então ele pensa: "se eu me tornei tão grande, outras pessoas também podem". O país teve por base indivíduos e a ideia de associação, de pessoas se unindo. As pessoas não dizem: "Sou apenas um indivíduo, o que posso fazer?"; elas pensam: "indivíduos podem fazer a diferença". Um grupo pode fazer mais, mas precisamos do empoderamento para o indivíduo contribuir para o grupo. Quando a mentalidade do Estado forte existe, o indivíduo não é empoderado e é difícil ver que se pode fazer a diferença dentro de um grupo ou comunidade.

O ideário do individualismo, que é muito forte nos Estados Unidos, está bem presente na fala de Jennifer. Ele é baseado na ideia de que uma sociedade é constituída a partir de indivíduos e que a ação deles resulta no bem de todos. Perguntada se ela acreditava que países como o Brasil poderiam se beneficiar das práticas e expertise norte-americanas e, em caso positivo, como, Jennifer respondeu empolgada: "imensamente". Para ela:

Os Estados Unidos têm um dos setores filantrópicos mais desenvolvidos do mundo com práticas testadas ao longo do tempo. Possui estruturas de doação - como fundações, marco legal, habilidades de gestão, capacidade de pessoal - para operar e perpetuar fundações e adaptar sua missão original às necessidades atuais. Possui, ainda, importante expertise, transparência no setor, advogados que atuam com a supervisão e fiscalização do setor e organizações que fornecem informações on-line. Nossa transparência é enorme, claro que ainda mais é necessário, mas pelo menos há a infraestrutura. Isso pode ser resumido em capacidade gerencial e administrativa, transparência, estratégias e quadro legal. Cada país deveria ter muita consciência da sua cultura e das motivações pelas quais as pessoas doam. Há muitos modelos interessantes e não se pode simplesmente importar um. 
No que concerne aos valores compartilhados por filantropos e investidores sociais, Jennifer ressaltou "um senso de obrigação e de contribuição para algo maior do que eles mesmos", o que remete à noção de que noblesse oblige (Elias 1994). Embora autores e pesquisadores como Bremner (1960) e Odendhal (1990) demonstrem a tradição filantrópica de elite como o grande jogo americano, que passa de forma intergeracional nas famílias de grandes fortunas, a interlocutora, ao se referir às motivações que levariam pessoas a fazer filantropia, indicou que isso seria algo muito pessoal e que:

As pessoas doam por diferentes razões. No fundo, elas doam porque encontram nisso grande satisfação. Elas se sentem bem, mexe com algo profundo, de ordem moral e às vezes elas recebem mais de volta do que os beneficiários ou recipientes.

Jennifer explicou que o papel do Global Philanthropy Forum é se constituir numa rede de filantropos que se reúnem para aprender uns com os outros, se tornando mais efetivos e estratégicos.

A organização é um lugar seguro para compartilhar práticas e conhecer outras pessoas na área da filantropia global. Pares em potencial, parceiros e líderes do mundo do desenvolvimento, da política e do setor privado.

Ao falar sobre a influência da filantropia nas políticas públicas e a advocacy de $\operatorname{causas}^{10}$, Jennifer justificou:

Advocacy é algo muito forte nos Estados Unidos. Estamos vendo a filantropia se tornar cada vez mais envolvida com advocacy. Legalmente, as fundações e ONGs não podem fazer trabalho político. Elas não podem ir ao Congresso e fazer lobby. No entanto, há uma série de organizações que apoiam certas causas como, por exemplo, o casamento gay [recentemente legalizado em alguns estados norte-americanos]. Então as fundações são, e nesse caso foram, uma parte desse processo. O que elas podem fazer é financiar programas que empoderem e contribuam para uma campanha. Elas contribuem com partes que servem a uma campanha mais ampla. Essa também é uma forma de advocacy, mas não é lobbying. Eu imagino que alguns filantropos apoiam distintas campanhas de advocacy.

O último ponto tratado foi a questão de gênero. Apesar de a presença de homens ser grande no universo filantrópico, Jennifer disse que a maior parte da riqueza está sendo doada por mulheres. Isso se daria porque elas tendem a viver mais tempo que seus maridos ou porque seus maridos estão ocupados fazendo dinheiro. A doação feminina tende a ir para causas como direitos de crianças, mulheres jovens, violência doméstica. 


\section{Filantropia Progressista ou de Justiça Social}

Na visão de nossos interlocutores, a filantropia progressista ou de justiça social se contrapõe ao filantrocapitalismo . Seus promotores argumentam que há uma falência do atual sistema socioeconômico e apostam em alternativas que propiciem a transição para um novo modelo. Essa mudança se daria pela construção de uma sociedade menos individualista e mais igualitária, justa e comunitária. Seus praticantes focam em ações e programas que possam mudar o modelo econômico e reduzir suas injustiças. Isso é feito através do financiamento de ativistas e movimentos sociais.

A filantropia progressista se alinha com autores que criticam a narrativa mítica do paradigma do desenvolvimento e seu discurso de uma linearidade evolutiva (Furtado, 2013). Eles assinalam o caráter predatório do atual sistema produtivo e a inviabilidade de, através dele, alcançar o crescimento econômico contínuo e sustentável com a universalização dos padrões de consumo dos países considerados desenvolvidos. Essa ideologia de uma modernização universal, que na prática não tem como se viabilizar, frequentemente submete populações inteiras à degradação de seus modos de vida e do meio físico. O desenvolvimento seria então um plano irrealizável das sociedades ditas "modernas", baseadas na racionalidade, estruturadas dentro de estados-nações e centradas na lógica do mercado (Bresser-Pereira, 2006).

Por isso, é preciso levar em conta que as nações são diferentes e que cada uma delas deve ter autonomia para construir seu próprio modelo de desenvolvimento, baseado em sua cultura e seus imaginários. Além disso, o desenvolvimento precisa ser sustentável e se preocupar com a liberdade, a justiça social e a proteção do meio ambiente.

Ao tratar das alternativas democráticas a um sistema neoliberal, Block indica haver "alternativa possível para o cenário em que a insustentabilidade do liberalismo de mercado acarreta crises econômicas e o ressurgimento do autoritarismo e de regimes agressivos". Para esse autor, a alternativa seria o engajamento de "pessoas comuns" em "esforço solidário para subordinar a economia à política democrática e à reconstrução da economia global, com base na cooperação internacional". Com efeito, esse movimento social teria dado seus sinais na década de 1990, demonstrando ser mais do que uma possibilidade teórica. Para ilustrar este argumento, Block assinala que "ativistas nos países desenvolvidos e em desenvolvimento organizaram protestos militantes contra as instituições internacionais - Organização Mundial do Comércio, Fundo Monetário Internacional e Banco Mundial" e assim começaram o diálogo "sobre a reconstrução da ordem financeira global" (Block 2012: 172-173). 
A filantropia progressista atribui o protagonismo da mudança não somente às elites, mas principalmente aos grupos de base e aos movimentos sociais. Ao contrário da versão filantrocapitalista, que visa aliviar a pobreza por meio de projetos criados pelos próprios capitalistas, a versão progressista da filantropia atribui às organizações de base a promoção de projetos de saída da pobreza e empoderamento dos pobres por eles mesmos, centrados nas demandas de movimentos sociais e ativistas. A filantropia progressista procura mobilizar e sensibilizar doadores a investirem em comunidades e projetos de base.

Um exemplo interessante que embasa a perspectiva da filantropia de justiça social e serve como chave analítica é o livro The end of capitalism (as we knew it): a feminist critique of political economy ( $O$ fim do capitalismo como nós o conhecíamos, uma crítica feminista da economia política) (2006) das geógrafas Julie Gibson e Katharine Graham ${ }^{10}$. Mais do que um trabalho acadêmico, as autoras propõem o engajamento com iniciativas que desconstruam a hegemonia do capitalismo e estimulem a imaginação e experiências de economias alternativas, por mais complexo que este termo possa ser. O projeto dessas autoras busca "abrir um espaço discursivo para a prevalência e diversidade econômica não capitalista ao redor do mundo" (2006: 10). Além disso, ele propõe a "produção de uma linguagem da diferença econômica para ampliar o imaginário econômico, tornando visíveis e inteligíveis as diversas e prolíferas práticas que a preocupação com o capitalismo obscureceu" (2006: 10). A terceira dimensão em sua proposta de pesquisa-ação é "o difícil processo de cultivar sujeitos (nós e outros) que possam desejar e habitar espaços econômicos não capitalistas (2006: 10).

Repensar a transformação das identidades individuais, encaradas não mais como fechadas e essenciais, mas como processuais e relacionais aparece como fundamental para rever estratégias econômicas. Gibson-Graham destacam o que chamam de uma "política do sujeito", que seria o processo de produzir "algo além das mudanças discursivas na identidade, algo que levaria em conta a experiência sensível e gravitacional de embodiment". Mudar a si mesmo seria mudar o mundo: "Enquanto uma prática de fazer história, o projeto de construir uma economia alternativa também envolve novas práticas do self, produzindo diferentes sujeitos econômicos por meio de uma micropolítica ou ética da autotransformação" (2006: 16). Para Gibson-Graham, assim como para outras autoras, o Fórum Social Mundial, cuja primeira edição ocorreu em Porto Alegre em 2001, é indiscutivelmente um espaço onde um novo imaginário político e social pode emergir.

A filantropia de justiça social, com frequência, tem um viés feminista que enfatiza a importância das emoções, da espiritualidade e da diversidade cultural. Autoras como Gibson-Graham assinalam que a economia e os 
negócios são uma arena eminentemente masculina. A lógica dominante é a da racionalidade, da métrica e do cálculo financeiro. Em contraposição, elas reivindicam uma prática alternativa que valorize os afetos e a solidariedade. Ao focar nos movimentos de base e no espaço comunitário, as autoras argumentam que é preciso abandonar a lógica masculina presente nos grandes negócios e finanças e atentar para os pobres e suas lógicas alternativas.

Referindo-se ao fato de que a atividade não-remunerada dos trabalhos considerados femininos como o cuidado com crianças, idosos e deficientes, o trabalho doméstico e o trabalho emocional é responsável por 50\% da economia mundial essas autoras assinalam que

O [pensamento] mais controverso, mas também o mais bem-sucedido contra o pensamento econômico dominante tem sido liderado por ativistas e economistas feministas, que apontam para a significativa quantidade de trabalho (muito do qual desempenhado por mulheres) gasto em atividades não remuneradas ou não voltadas ao mercado tais como trabalho doméstico, voluntariado, criação de filhos e cuidado com idosos e enfermos. Trabalho empírico no assunto tem estabelecido que em ambos países ricos e pobres, 30 a 50 por cento da atividade econômica é contabilizada pela atividade doméstica não remunerada (...). Existe agora uma chamada para que o sistema nacional de contas seja revisto para que a medida total de performance econômica, produto econômico bruto, inclua ambos o produto bruto de mercado e o produto bruto doméstico(...) (Gibson-Graham, 2006:11).

Uma instituição que congrega os filantropos progressistas nos Estados Unidos é a Edge Funders Alliance (EFA), organização internacional que procura sensibilizar doadores a contribuírem para projetos de comunidades de base. De acordo com o site da organização ${ }^{11}$,

A Edge Funders Alliance se organiza nos marcos da filantropia para elevar a consciência e aprofundar a compreensão da natureza interconectada das crises sociais, econômicas e ecológicas que ameaçam nosso futuro comum. A EDGE trabalha para aumentar os recursos para comunidades e movimentos, criando alternativas de mudanças sistêmicas para uma transição para uma sociedade que apoia a justiça, a equidade e o bem-estar do planeta.

É interessante ouvir ativistas que atuam no setor da filantropia pela justiça social. Karen, membro do EFA, é diretora da Channel Foundation, uma pequena fundação familiar que financia projetos de justiça de gênero e direito das mulheres, principalmente as indígenas. No site da organização, que fica em Seattle, cidade do noroeste dos Estados Unidos, lê-se 
A Fundação promove liderança em direitos humanos das mulheres ao redor do globo, dando suporte a organizações engajadas em combater desigualdade de gênero. Por meio de doações, advocacy e colaboração com uma rede internacional de organizações e financiadoras de direitos das mulheres (tais como Fundo Elas, ONU Mulheres, AWID, Fondo Acción Urgente [de América Latina y el Caribe], Astraea the Lesbian Foundation for Justice, Mama Cash, Prospera entre outras) criamos oportunidades para assegurar que os direitos das mulheres sejam respeitados, protegidos e realizados.

Referindo-se ao Global Philanthropy Forum, Karen prontamente disse: "ah, essa rede é muito de direita, vocês precisam conhecer a nossa que é mais de esquerda". Ela explicou que enquanto algumas organizações e mesmo intelectuais trabalham com a noção de filantropia baseada em técnicas empresariais e sustentada pelo financiamento entre pares de negócios, sua rede seria mais progressista e transformadora, apostando no financiamento de ativistas e movimentos sociais. Assim, Karen nos colocou em contato com Peter, diretor da Edge Funders Alliance.

Ele relatou um pouco de sua trajetória:

Eu passei em torno de vinte e cinco anos trabalhando com o paradigma de desenvolvimento internacional. Nos anos setenta, quando saí da faculdade, entrei para o Peace Corps, fui voluntário na África, trabalhei para financiadores e ongs, morei e trabalhei na Ásia, trabalhei com o USA for Africa, com a Oxfam e peguei uma época em que as ongs da África estavam pressionando por um desenvolvimento liderado mais endogenamente e comecei a repensar o desenvolvimento internacional...

Peter contou a passagem de seu enfoque no desenvolvimento para o seu interesse na justiça social. No final dos anos 90, ele estava trabalhando para uma fundação focada em jovens em San Francisco, quando em 1999 eclodiu o movimento que ficou conhecido como a "Batalha de Seattle", no contexto dos protestos que aconteceram nessa cidade face à reunião da Organização Mundial do Comércio que estava lá ocorrendo. Ele organizara então um grupo que participou dos protestos, o que ele chama de emergência dos movimentos antiglobalização.

Então, essa foi realmente a transição e esse movimento mudou completamente a minha noção de desenvolvimento em direção ao paradigma da justiça social. Nós levamos quarenta jovens da Bay Area [região da baía de San Francisco, California] para Seattle (...) éramos um dos poucos contingentes formados por jovens ativistas negros, estudantes e não-estudantes e isso era parte daquele debate. 
Peter relata o questionamento acerca da ausência das chamadas "minorias", especialmente de pessoas e movimentos negros nas manifestações em Seattle:

Vários dos grupos que estavam muito engajados como Global Exchange e Rain Forest Action Network eram organizações internacionalistas, o que é ótimo, mas o argumento sendo colocado pelas pessoas mais jovens em nossas organizações foi o que levou à noção de translocalização, translocalismo. Não eram grupos internacionais que deveriam estar à frente, deveriam ser grupos em Oakland, ligados a grupos em Detroit, ligados a grupos em Porto Alegre, sabe? Então tinha que ser local, tinha que ser grassroots.

Sua trajetória prosseguiu com a coordenação da Funders Network on Trade and Globalization, uma rede de financiadores que participaram dos eventos em Seattle. Dentre estes financiadores, Peter destacou duas vertentes de financiamento: uma para ongs e organizações internacionais e outra para organizações comunitárias e organização de movimentos sociais. A partir da sua atuação nessa rede, ele contou que começou o envio de delegações de financiadores a encontros do Banco Mundial, encontros ministeriais da Organização Mundial do Comércio, cúpulas climáticas e ao Segundo Fórum Social Mundial realizado em Porto Alegre em 2002.

Ao final da entrevista, Peter sugeriu que procurássemos Mariana, uma feminista e acadêmica colombiana, componente do quadro diretivo da Gender Justice Initiative, ligada a Edge Funders Alliance e dirigida por ele e formada por financiadores, movimentos sociais e ativistas. Ela trabalha em um fundo de justiça de gênero e direito das mulheres.

A temática de gênero e feminismo funciona como fio condutor do universo filantrópico em geral para diversos atores da rede de filantropia progressista e de justiça social. Mariana estudou nos Estados Unidos nos anos 80 e fez seu mestrado em estudos de gênero. Ela iniciou sua carreira no setor como uma das primeiras voluntárias do Rain Forest Action Network, após conhecer Randy Hayes, fundador dessa rede e diretor-executivo da Foundation Earth, uma nova organização que se propõe a ajudar a proteger os sistemas de apoio da vida no planeta. Ela trabalhou na ONU, na organização Pan Americana de Saúde. Foi também assessora da Astraea, Mama Cash, Global Fund for Women e mais tarde do Urgent Action Fund Latin America.

Todas as organizações citadas por Mariana fazem parte da rede Gender Justice Initiative. Indagada sobre as diferentes perspectivas do universo filantrópico, no qual alguns financiadores são indicados como mais conservadores e outros mais progressistas, Mariana destacou sentir haver uma diferença clara entre essas distintas abordagens. 
(...) mesmo aqueles que atuam em direitos humanos. Isso não implica necessariamente que eles tenham um entendimento holístico dos direitos humanos ou que ataquem as causas da desigualdade. Então eu diria que alguns financiadores têm o discurso, mas não buscam mudanças estruturais e outros sim. Nesse caso acho que a rede (ligada à Edge Funders Alliance) representa uma abordagem mais poderosa em direção a mudanças estruturais.

Ao abordar o modo através do qual sua rede enxerga a transição para uma sociedade mais justa, Mariana destacou a influência que recebe em seu trabalho do pensamento pós-colonial. Para ela, pensar uma transição linear, como se fôssemos passar do capitalismo a outro sistema de forma estática e linear é problemático: "esse é um dos maiores desafios mesmo para a filantropia progressista, mover-se de um ponto de vista ocidental que é linear para um entendimento mais dinâmico dos processos e mudanças nas realidades sociais".

Ao falar das origens dos financiamentos, Mariana indicou que a maior parte dos recursos que recebe vem do governo holandês e de financiadores dos Estados Unidos e da Europa: "muito pouca coisa vem de doações individuais". Quanto à ligação com o Brasil, Mariana citou o Fundo Elas, "nosso fundo-irmão", e contou receber pedidos de doações de movimentos e ativistas de toda a América Latina "principalmente de defensoras de terras e de territórios, protetoras ambientais". Acerca da abordagem feminista no universo filantrópico, Mariana explicou que focar na desigualdade e na injustiça não necessariamente implica que as dimensões do gênero e do feminismo estejam no centro da filantropia progressista:

Eu acho que enquanto movimentos de mulheres nós somos agora um assunto inevitável em termos de entendimento de mudanças políticas e sociais... Mas acho que ainda precisamos nos aprofundar no que isso implica. Precisamente porque sentíamos que o gênero não era um assunto crucial com o qual estava se lidando em profundidade é que a iniciativa foi criada. Nós temos que lembrar que mesmo na nossa região e no mundo todo, os movimentos e as ideologias de esquerda e progressistas sempre pensaram que depois que a revolução fosse feita então lidariam com as questões das mulheres, então eu acho que também tem a ver com a linguagem com a qual a esquerda pensa sobre mudança e transformação.

Acerca do fundo no qual atua, Mariana explicou financiarem defensores dos direitos humanos das mulheres "para que tenham liderança nas ações que querem tomar para transformar situações de opressão, exploração ou discriminação": 
Nós somos um fundo feminista. Sim, há muitos tipos diferentes de feminismo, mas nosso feminismo é progressista, não liberal. Não queremos apenas mudanças na legislação, nós queremos mudanças estruturais... Então lidamos com as múltiplas questões que tem a ver com as identidades das mulheres, suas sexualidades, idades, capacidades e deficiências... Ser uma mulher é uma coisa, ser uma mulher negra que é pobre ou marginalizada é totalmente diferente e se você tem uma orientação sexual que é diferente da matriz heterossexual também é completamente diferente, então todos esses elementos jogam quando se trata de transformar a situação das mulheres e dos movimentos sociais em geral... Feminismo para mim não é apenas uma teoria, é também uma prática, uma ética, implica cuidado.... nós não recebemos dinheiro de quem explora aquelas que defendemos. Não aceitamos dinheiro de corporações, por exemplo.

Mariana indicou então a centralidade de uma ética do cuidado ${ }^{12}$ que perpassa seu trabalho prático e acadêmico. O foco de ação dessa rede de financiadores que busca colocar a justiça de gênero e direito das mulheres em uma perspectiva interseccional dentro da pauta da filantropia e de diversos movimentos sociais está alinhado com as elaborações da teoria engajada de Gibson-Graham que aposta na diversidade e nas iniciativas de âmbito local conectadas em rede, para alcançar potencialmente mudanças sistêmicas. Mariana explica:

Eu acho que precisamos aprender que essa questão do mundo ocidental é absolutamente crítica. Eu acho que a América Latina está sendo ensinada e lembrada por descendentes afro e por povos indígenas que existem outras formas de viver, que existem outras formas de entender a vida e formas de bem viver com seres humanos e outros seres que são outras formas de vida. Por outro lado, estamos sendo ensinados pelos movimentos que uma política de identidade não é o que vai mudar o mundo; por exemplo, no Chile mulheres lésbicas estão apoiando a luta do povo Mapuche. Então elas não precisam imputar o ser lésbica para lutar por uma causa, elas estão apoiando a causa de outros, de mulheres indígenas e é uma forma de relação muito única, uma rede e dificuldades comuns.... eu acho que um entendimento complexo da realidade, uma abordagem mais dinâmica e não-ocidental são necessários, porque não é somente o capitalismo, é o entendimento ocidental do norte, a mente racional linear que realmente orientou paradigmas de desenvolvimento e direitos humanos e isto está sendo questionado e já não é mais sustentável, o que eu acho ótimo, mas nós precisamos sacudir as estruturas não apenas dos sistemas econômicos mas também dos sistemas de pensamento, como as pessoas pensam, nós precisamos questionar isso, nós precisamos questionar a filantropia, as relações de poder entre norte e sul mesmo que sejam progressistas. 
Lembrando os dados apontados por Gibson-Graham de que a atividade não-remunerada dos trabalhos considerados "femininos" como o cuidado, o trabalho doméstico e o trabalho emocional seriam responsáveis por metade da economia mundial, Mariana destacou que não há sentido em fazer qualquer forma de filantropia visando acabar com a pobreza e encarar a desigualdade social sem que se coloque a questão interseccional da justiça de gênero como seu fio condutor:

Eu acho que é mais do que isso. Não é apenas deslocar o poder dos homens para as mulheres. Eu acho que é importante ter práticas mais democráticas entre homens e mulheres em geral, embora eu saiba que "democracia" é um termo que também está sendo questionado... Eu acho que é sobre justiça... em termos de mudanças nós, humanos, homens e mulheres de qualquer orientação sexual ou identidade de gênero ou raça precisamos pensar sobre como nos relacionamos com o meio ambiente e todos os outros viventes.... Qualquer nova sociedade não pode ser construída se não agirmos em relação ao racismo histórico, estrutural, se não agirmos contra a perversidade de impor uma matriz heteronormativa e também contra a desigualdade econômica entre seres humanos. Por exemplo, na matriz da transição justa, a espiritualidade foi um item colocado, trazida por alguns de nós, por fundos que trabalham com indígenas, mas acho que também tem vindo de outros movimentos... eu acho que na América Latina para povos indígenas e para pessoas de ascendência africana a espiritualidade está no centro das mudanças e isso pode não ser entendido no Ocidente. Vemos Beta Cáceres [líder indígena de Honduras assassinada em 2016 e homenageada pela rede no seu congresso do mesmo ano] dizendo "eu estou aqui para lembrar a humanidade, por favor, parem. Eu estou defendendo o rio Gualcarque que é o espírito das mulheres e as guardiãs desse rio são as meninas na cultura Lenca". Então eu acho que isso precisa ser repensado e o feminismo tem potencial para isto. Não se trata apenas o capitalismo, mas do patriarcado, da abordagem ocidental à vida. Você precisa ver o trabalho desde uma perspectiva descolonial, porque é disso que eu estou falando....

A partir da fala de Jennifer, Karen, Peter e Mariana podemos perceber a coexistência de duas narrativas no campo filantrópico norte-americano: a da manutenção e aprimoramento de uma ordem social vigente com foco nos negócios, no empreendedorismo e no capitalismo, e a narrativa da transição para uma economia considerada mais justa. Apesar disso, também identificamos similaridades como o intuito de influenciar políticas públicas, a gestão de populações com o estabelecimento de laços sociais, e o protagonismo de atores sociais, sejam eles experts, intelectuais ou líderes de movimentos sociais. 


\section{IV}

Há várias motivações que levam pessoas a praticar a filantropia. Um das delas tem um caráter altruísta: fazer o bem a outrem. Outra apresenta uma dimensão egoísta: amenizar o sofrimento dos pobres para manter funcionando o sistema que beneficia quem pratica a doação. Altruísmo e egoísmo são conceitos desenvolvidos por Durkheim (2019). Ele também introduziu a ideia de solidariedade orgânica como o fundamento da sociedade moderna, já que estava preocupado com as bases morais da vida social (Durkheim 2015).

Altruísmo e egoísmo não são excludentes e tampouco constituem as únicas motivações da filantropia. Baseados em nossa pesquisa, gostaríamos de argumentar que a dimensão mais importante da filantropia é a obrigação moral: o filantropo se vê beneficiado por uma sociedade que lhe permitiu enriquecer e por conseguinte sente-se obrigado a retribuir os resultados de seu sucesso, ajudando àqueles que não tiveram a mesma possibilidade. A noção de obrigação moral aparece repetidamente na fala de nossos entrevistados e na justificativa da filantropia ou da doação de recursos privados para o bem público.

O filósofo australiano Peter Singer, professor da Universidade de Princeton, é um dos fundadores do movimento denominado Altruísmo Eficaz e defensor da obrigação moral em fazer filantropia. Para ele, não há indícios de que o capitalismo desapareça em um horizonte próximo e, portanto, o investimento filantrópico maximizando o bem comum seria uma das únicas formas de contornar seus inúmeros problemas éticos (Singer 1972, 2011, 2017). Na obra de Singer, o que é visto como moralmente condenável não é a desigualdade social, mas a pobreza e o sofrimento. Nessa perspectiva, os filantropos tendem a ser vistos como "os mais fortes" que têm a responsabilidade de zelar pelos "mais fracos". Para que isso aconteça é preciso que haja a naturalização da importância da retribuição.

Embora a filantropia goste de ser encarada como uma prática moderna e "científica", há obviamente algo "religioso" nessa perspectiva da obrigação moral. O primeiro elemento é o sentido de ajudar os fracos e assim praticar o bem, mesmo que o discurso seja diferente da caridade. O segundo é o efeito da ética protestante no espírito capitalista (Weber 1970) que é forte nos Estados Unidos e que vê no trabalho uma forma e enaltecer a obra de Deus, enxergando no sucesso financeiro um sinal da salvação. Portanto, o dinheiro deixa de ser algo que pode ser gasto sem preocupações morais e a doação é uma forma de purificar o dinheiro. 
Analisando a Holanda no século XVII, em sua assim chamada Idade de Ouro, Schama mostrou que "a riqueza causava desconforto e que a abastança convivia com a ansiedade". Para ele,

(..) o credo oficial do calvinismo e do humanismo concordavam em que o lucro era algo sujo e que cultuá-lo constituía uma espécie de idolatria aviltante. Em suas formas extremas de avareza e cupidez, podia perturbar a consciência e a razão e transformar almas livres em escravos bajuladores. Essa forte concepção da natureza repreensível do enriquecimento persistiu mesmo enquanto os holandeses acumulavam suas fortunas individuais e coletivas. A estranha consequência dessa disparidade entre princípios e prática foi estimular os gastos de capital a fim de afastar a suspeita de avareza. As formas de tais gastos tinham de ser sancionadas coletivamente e consideradas impecáveis do ponto de vista moral tanto pelos clérigos quanto pelos leigos. Contudo podiam ir dos gastos virtuosos, como a filantropia, a gastos menos altruístas, como emprestar dinheiro a instituições públicas a juros baixos e prazos longos, ou mesmo à necessidade de criar um ambiente doméstico confortável, no qual uma patriótica família cristã pudesse viver (Schama 324, 330-332).

Nessa perspectiva, a filantropia transforma a obtenção de fortunas em algo que implica responsabilidade moral em relação aos menos afortunados. Mas, é claro que a obrigação de doar não exclui uma competição entre filantropos. Assim, as motivações da filantropia podem também incluir a busca de prestígio e de poder. Isso coloca a questão de saber se a filantropia é algo desinteressado ou se há interesses nessa prática. Ao analisar sociedades contemporâneas, Bourdieu criou a expressão "interesse no desinteresse" e assinalou que as relações sociais ditam comportamentos que correspondem às posições dos atores sociais:

Os universos sociais nos quais o desinteresse é a norma oficial não são, sem dúvida, inteiramente regidos pelo desinteresse: por trás da aparência piedosa e virtuosa do desinteresse, há interesses sutis, camuflados (...) não se vive impunemente sob a invocação permanente da virtude, já que somos apanhados pelos mecanismos e pelas sanções que existem para relembrar a obrigação do desinteresse (Bourdieu, 2008: 152).

Nesse sentido, fazer grandes doações significa, além de uma obrigação moral, a obtenção de reconhecimento entre os pares e a sociedade como um todo. Witkowski e Bauerkämper (2016: 2), associam a obrigação moral com a busca do reconhecimento social: 
Doadores normalmente esperam alguma recompensa pelo seu apoio, como por exemplo reconhecimento, prestígio ou mesmo ganhos financeiros. Especialmente as elites em ascensão normalmente buscam converter o capital econômico em reconhecimento, status e prestígio ("capital social" e "cultural" de acordo com Pierre Bourdieu). Essas interpretações sugerem que doar é devido a motivos altruístas e interesses particulares.

A prática da filantropia coloca os doadores num circuito que cria relações interpessoais que são importantes no estabelecimento de conexões e redes sociais. De algum modo, não praticar filantropia exclui o magnata do círculo de seus pares. Nesse sentido, Adloff argumenta que os filantropos "frequentemente se sentem conectados a outras pessoas e suas preocupações ou problemas, considerando a si mesmos como tendo uma ligação e uma obrigação com grupos específicos, ou mesmo estando envolvidos com eles num nível prático por meio de redes formais e informais" (Adloff 2016: 45).

Neste artigo, examinamos as premissas que movem os agentes do filantrocapitalismo, baseadas em discursos e lógicas empresariais e visando manter e mesmo ampliar seus lucros via filantropia. Da mesma forma, analisamos a filantropia que se quer progressista e que desenvolve uma visão mais protagônica de movimentos sociais, propondo-se a fazer filantropia a partir de uma perspectiva de justiça social. Os discursos e as lógicas nas quais operam o filantrocapitalismo e a filantropia para a justiça social são bastante distintos. A premissa do desenvolvimento e do papel da elite em promovê-lo aparece como central no ethos filantrocapitalista, ao passo que a filantropia progressista tenta se distanciar dessa perspectiva, focando no papel dos movimentos sociais e na organização dos grupos populares. Em ambas as vertentes são recorrentes os argumentos de que a filantropia visa solucionar questões sociais, mas é complexa e requer expertise e aprendizados próprios ao campo.

Os filantrocapitalistas acreditam que o Estado e sua burocracia não conseguem promover de forma eficaz uma ação distributiva e que isso deve ser feito por fundações pensadas pelos ricos e praticado sob forma capitalista, já que o mercado funciona melhor que o Estado. Por sua vez, os adeptos da filantropia pela justiça social pensam que o capitalismo cria desigualdades que o sistema e o Estado não conseguem resolver e a filantropia pode ajudar a corrigir isso nos Estados Unidos e em países em desenvolvimento, a partir do protagonismo de movimentos sociais.

Seria a filantropia uma narrativa inerente ao capitalismo global para atenuar as desigualdades que ele causa ou poderia ela ser efetiva se pensada em termos de redistribuição de renda e poder e de reparação a grupos 
e regiões historicamente explorados? A filantropia incorpora o paradoxo de querer equacionar problemas sociais causados muitas vezes por seus próprios doadores. Não são poucas as referências que demonstram que magnatas têm práticas de exploração e corrupção em suas empresas de um lado, e uma fundação filantrópica para servir à comunidade de outro. No entanto, existem também fundos que estão sendo geridos pelas comunidades de base e, como Odendahl (1990: 189) aponta, fundos de mulheres - muitas que herdaram suas fortunas - que constroem narrativas e trajetórias distintas acerca da redistribuição de renda e da desigualdade social.

Um pensamento dualista levaria a ver nos movimentos sociais alternativos a negação do pensamento colonialista e a tentativa de criação de um mundo não capitalista. No entanto, autoras como Gibson-Graham e interlocutores como Peter e Mariana advogam pela complexificação desse pensamento, descentrando as análises do capitalismo para abordar um conjunto de possibilidades dissidentes que atuam na esfera econômica em iniciativas diversas, a fim de poder se imaginar um outro mundo possível.

Independentemente de nos posicionarmos num polo mais negativo ou mais positivo em relação à filantropia, é fato que as regulações e isenções fiscais para a sua prática existem e governos, fundações privadas e o terceiro setor vêm operando de forma interligada com disputas constantes acerca dos focos de investimento e a forma de utilizá-los. A filantropia certamente é uma importante prática social que precisa ser levada em consideração quando pensamos o mundo moderno e as diferentes formas de lidar com suas desigualdades.

A filantropia é uma prática de sociedades complexas, nas quais a desigualdade e a pobreza constituem uma preocupação moral de elites. Ela movimenta grandes somas de dinheiro e cria um mercado de doações através do qual várias organizações, mesmo as que criticam a sociedade capitalista, disputam recursos. Essas organizações desenvolvem diferentes perspectivas e estratégias a respeito de como atuar. Apesar de envolver a doação de vastas somas de dinheiro, a filantropia não é uma dádiva semelhante àquela presente em sociedades arcaicas, como as analisadas por Mauss no célebre ensaio em que ele examinou o potlatch como um sistema de prestações totais. As sociedades complexas têm outra escala, estão divididas em classes sociais e são marcadas pelas desigualdades, apesar de frequentemente professarem um ideário de que todos os cidadãos são iguais. Por isso, a filantropia procura responder a uma questão moral que tem a ver com o fato de a riqueza de uns contrasta com a pobreza de outros. A filantropia é simultaneamente um mercado, uma obrigação moral, uma forma de interesse e uma maneira de os membros de elites estabelecerem redes entre eles. 
Recebido em: 22 de novembro de 2019

Aprovado em: 03 de fevereiro de 2020

Patricia Kunrath Silva

Doutora pelo Programa de Pós-Graduação em Antropologia Social da Universidade Federal do Rio Grande do Sul, é professora da Escola Superior de Marketing e Propaganda em Porto Alegre. É membro do Núcleo de Pesquisas sobre Culturas Contemporâneas da UFRGS, do Grupo de Estudos em Antropologia da Economia e da Política da UFRGS e do Grupo de Estudos de Empresas e Organizações da PUCRS. Entre seus interesses de pesquisa estão: desigualdade e justiça social, cidadania, governança, elites, filantropia, feminismos, mercados e consumo.

Filiação Institucional: Escola Superior de Marketing e Propaganda, Porto Alegre. https://orcid.org/0000-0002-4821-5508

E-mail: patrícia.kunrath@gmail.com

\section{Ruben George Oliven}

Doutor pela Universidade de Londres, é professor titular do Programa de Pós-Graduação em Antropologia Social da Universidade Federal do Rio Grande do Sul, pesquisador 1A do CNPq e membro da Academia Brasileira de Ciências. Foi presidente da Associação Brasileira de Antropologia e da Associação Nacional de Pós-Graduação e Pesquisa em Ciências Sociais. Foi professor visitante em várias universidades estrangeiras, entre elas a Universidade de Londres, a Universidade de Paris, a Universidade de Leiden e a Universidade da Califórnia, Berkeley. Entre suas publicações está A Parte e o Todo: a diversidade cultural no Brasil-nação, livro agraciado com o Prêmio Melhor Obra Científica de Ciências Sociais do Ano e traduzido para o inglês e o espanhol. Recebeu o Prêmio Érico Vannucci Mendes por sua contribuição ao estudo da Cultura Brasileira e o Prêmio ANPOCS de Excelência Acadêmica Gilberto Velho em Antropologia. Em 2018 foi agraciado com a Grã-Cruz da Ordem Nacional do Mérito Científico.

Filiação institucional: Programa de Pós-Graduação em Antropologia Social da UFRGS

https://orcid.org/0000-0003-3556-6955

E-mail: ruben.oliven@gmail.com 


\section{Notas}

1 A pesquisa que deu origem a este artigo contou com o apoio do Conselho Nacional de Desenvolvimento Científico e Tecnológico - CNPq.

2 Acessível em: https://g1.globo.com/economia/negocios/noticia/bill-gates-faz-maior-doacao-de-sua-fortuna-desde-2000.ghtml

3 Luciano Andolini. "Bill Gates e 40 bilionários tentam mudar o mundo". Papo de Homem. Trabalho e negócios, Mundo. Acessível em https://papodehomem.com.br/ bill-gates-e-40-bilionarios-tentam-mudar-o-mundo/

4 Para ver as concessões tributárias norte-americanas acessar www.irs.gov/charities-non-profits/charitable-organizations/charitable-contribution-deductions Acessado em 16 de dezembro de 2017.

5 Ver https://www.alliancemagazine.org/feature/philanthrocapitalism-goes-global/

6 Ver http://www.worldaffairs.org/

7 Ver https://www.philanthropyforum.org/

8 Os nomes das pessoas entrevistadas nesta pesquisa foram mudados para preservar sua privacidade.

9 Advocacy é um termo que designa iniciativas que se envolvem com a defesa de causas ou de propostas de interesse público. As ações de advocacy procuram intervir na elaboração de políticas públicas, influenciando, por exemplo, os responsáveis por tomadas de decisões e elaboração de leis.

10 Essas duas autoras compartilham o nome autoral singular Graham-Gibson.

11 Disponível em https://edgefunders.org/about-us/

12 De acordo com Zirbel (2016): "A Ética do Cuidado pode ser dividida em duas fases ou gerações de pensadoras. A primeira delas foi dedicada a descrever os dispositivos e atitudes do cuidado associando-os a certas emoções e virtudes, buscando demonstrar os limites de uma visão racionalista para questões morais, de justiça e direitos. A segunda geração tem enfatizado a vulnerabilidade e as necessidades humanas como aspectos relevantes para a moralidade e a política. Em comum, ambas as gerações defendem o cuidado como uma responsabilidade individual e coletiva e um bem público". Ver também Cordero Velásquez e Ilyas. Disponível em: https:// www.opendemocracy.net/openglobalrights/meerim-ilyas-tatiana-cordero-vel-squez/ el-cuidado-colectivo-en-la-financiaci-n-de-l 


\section{Referências bibliográficas}

ADLOFF, Frank. "Philanthropic Giving: Reasons and Constellations". In: WITKOWSKI, Gregory \& BAUERKÄMPER, Arnd (orgs.). German Philanthropy in Transatlantic Perspective. Perceptions, exchanges and transfers since the early twentieth century. Cham: Springer, 2016, pp.41-54.

BISHOP, Matthew \& GREEN, Michael. Philantrocapitalism. How the Rich Can Save the World. New York: Bloomsbury Press, 2008.

BLOCK, Fred. "Introdução". In: POLANYI, Karl. A Grande Transformação. Lisboa: Edições 70, 2013, p. 130-179.

BONNAFOUS-BOUCHER, Maria. "From Government to Governance". In: Ethical Perspectives: Journal of the European Ethics Network, 12(4), 2005, p. 521-534.

BOURDIEU, Pierre. "Será possível um ato desinteressado?" In: Razões Práticas. Sobre a teoria da ação. Campinas: Papirus, 2008, p. 137-156.

BREMNER, Robert H. American Philanthropy. Chicago: The University of Chicago Press, 1960.

BRESSER-PEREIRA, Luiz Carlos. O conceito histórico de desenvolvimento econômico. 2006. Disponível em bresserpereira.org.br/papers/2006/06.7-conceitohistoricodesenvolvimento.pdf.

CARRIER, James G. "Putting Parry's lecture in place". History and Anthropology 28(5): 559-563, 2017.

DURKHEIM, Emile. O Suicídio. São Paulo: WMF Martins Fontes, 2019.

DURKHEIM, Emile. A Divisão do TrabaIho Social. São Paulo: Edipro, 2015.

EDWARDS, Michael. Just Another Emperor. The Myths and Realities of Philanthrocapitalism. New York: Demos, 2008.

ELIAS, Norbert. Uma História dos Costumes, (v. 1 de O Processo Civilizador). Rio de Janeiro: Jorge Zahar, 1994.

FURTADO, Celso. Essencial. São Paulo: Editora Schwarcz, 2013.

GIBSON-GRAHAM. J.K. The end of capitalism (as we knew it): a feminist critique of political economy. Oxford: Blackwell. 2006.

GREGORY, Cristopher. "Parry, Trautmann and the 'alienable' gift". History and Anthropology 28(5): 564-568, 2017.

HANSON, John H. 2015. "The Anthropology of Giving: Toward a Cultural Logic of Charity". Journal of Cultural Economy 8(4): 501-520, 2015.

HART, Keith. "Marcel Mauss: In Pursuit of the Whole. A Review Article". Comparative Studies in Society and History 49(2): 473-485, 2007.

HIRATA, Helena. "Gênero, classe e raça. Interseccionalidade e consubstancialidade das relações sociais. In.: Tempo Social 26(1): 61-73. 2014.

KATZ, Stanley N. "What Does It Mean to Say that Philanthropy is 'Effective'? The Philanthropists' New Clothes". In: Proceedings of The American Philosophical Society 149(2), 2005.

KOHL-ARENAS, Erica. The Self-Help Myth. How Philanthropy Fails to Alleviate Poverty. Berkeley: University of California Press, 2016.

LAIDLAW, James. "A Free Gift makes no Friends". Journal of the Royal Anthropological Institute (n.s.) 6: 617-634, 2000.

LAIDLAW, James. "An axial essay". History and Anthropology 28(5): 568-571, 2017.

LÉVI-STRAUSS, Claude. "Introdução à Obra de Marcel Mauss". In: MAUSS, 
Marcel. Sociologia e Antropologia. São Paulo: Cosac Naify, 2003 [1950]. MAURER, Bill. "Entrevista". In.: Horizontes Antropológicos 22(45), 2016: 395-408. Disponível em http://www. scielo.br/pdf/ha/v22n45/0104-7183ha-22-45-0395.pdf

MAUSS, Marcel. "Da dádiva e, em particular, da obrigação de retribuir os presentes". In: Sociologia e Antropologia. São Paulo: Cosac Naify, 2003, p. 314.

ODENDAHL, Teresa. Charity begins at home. Generosity and self-interest among the Philanthropic Elite. New York: Basic Books, 1990.

OLIVEN, Ruben George. "De Olho no Dinheiro nos Estados Unidos". Estudos Históricos 15(27), 2001: 206-235.

PAPYROU, Stavroula. "Altruism and Sacrifice: Mafia Free Gift Giving in South Italy". Social Forum 24(4): 412-426, 2014.

PARRY, Jonathan. "The Gift, the Indian Gift and the 'Indian Gift'." Man (n.s.) 21(3): 453-473, 1986.

PARRY, Jonathan. "Mauss and King Arthur's round table". History and Anthropology 28(5): 580-583, 2017.

PUTNAM, Robert D. Our Kids: The American Dream in Crisis. New York: Simon \& Schuster, 2016.

SANCHEZ, Andrew. "The novelty of the gift: A British anthropologist \& the trends of ethnography". History and Anthropology 28(5): 559-563, 2017.

SANGLARD, G. P. Entre os salóes e o laboratório: filantropia, mecenato e práticas científicas. Rio de Janeiro, 1920-1940. Tese apresentada ao curso de Pós-Graduação em História das Ciências da Saúde da Fundação Oswaldo Cruz. Rio de Janeiro, 2005.

SCHAMA, Simon. O Desconforto da Riqueza. A Cultura Holandesa na Época de Ouro. São Paulo: Companhia da Letras, 1992.
SIGAUD, Lygia. "As Vicissitudes do 'Ensaio sobre o Dom'". Mana 5(2): 89-124, 1999.

SILBER, Ilana. "La philanthropie moderne à la lumière de Marcel Mauss". In: CHANIAL, Philippe. La société vue du don. Paris: Édition La Découverte, 2008.

SINGER, Peter. "Famine, Affluence, and Morality". Philosophy and Public Affairs 1(3): 229-243, 1972.

SINGER, Peter. A vida que podemos salvar. Agir agora para pôr fim à pobreza. Lisboa: Gradiva, 2011.

SINGER, Peter. O maior bem que podemos fazer. Lisboa: Edições 70, 2017.

STRATHERN, Marilyn. "Interests". History and Anthropology 28(5): 571-575, 2017.

THE ECONOMIST. "Survey: The birth of philathrocapitalism". 378(8466): 9, 25 de fevereiro de 2006.

VENKATESAN, Soumhya. "The Social Life of a 'Free' Gift". American Ethnologist 38(1): 47-57, 2011.

WEBER, Max. The Protestant Ethic and the Spirit of Capitalism. London: Unwin, 1970.

WITKOWSKI, Gregory R. \& BAUERKÄMPER, Arnd. "German Philanthropy in International and Transnational Perspective". In: German philanthropy in Transatlantic Perspective. Perceptions, exchanges and transfers since the early twentieth century. Cham: Springer, 2016, p. 1-20.

YAN, Yunxiang. "The Disenchantment of the gift". History and Anthropology 28(5): 576-580, 2017.

ZIRBEL, Ilze. Uma teoria político-feminista do cuidado. Tese de doutorado submetida ao Programa de Pós-Graduação em Filosofia da Universidade Federal de Santa Catarina. Florianópolis, 2016. 


\section{FILANTROCAPITALISMO VERSUS \\ FILANTROPIA PARA A JUSTIÇA \\ SOCIAL: UM DEBATE NORTE- \\ AMERICANO SOBRE COMO \\ LIDAR COM A POBREZA}

\section{Resumo}

Este artigo se propõe a analisar a filantropia norte-americana como uma prática através da qual os ricos retribuem parte da riqueza que conseguiram acumular e como um mecanismo para atenuar a pobreza dos menos bemsucedidos. São analisadas duas formas de filantropia e seus pressupostos: o filantrocapitalismo e a filantropia para a justiça social. Em ambos os casos é apresentado material de uma pesquisa realizada nos Estados Unidos com representantes dessas duas vertentes. A filantropia é discutida à luz da dádiva, do interesse e do desinteresse nas práticas sociais, e da obrigação moral.

Palavras-chave: filantropia, filantrocapitalismo, filantropia para justiça social, pobreza, dinheiro, Estados Unidos.

\section{PHILANTHROCAPITALISM VERSUS PHILANTHROPY FOR SOCIAL JUSTICE: A NORTH AMERICAN DEBATE ON HOW TO DEAL WITH POVERTY}

\section{Abstract}

This article analyzes North American philanthropy as a practice through which the rich return part of the wealth they were able to accumulate, and as a mechanism for alleviating the poverty of the less successful. Two forms of philanthropy are analyzed: philantrocapitalism and philanthropy for social justice. In both cases data deriving from research carried out in the United States with representatives of those two perspectives is presented. Philanthropy is discussed in light of the gift, interest and disinterest in social practices, and moral obligation.

Keywords: philanthropy, philanthrocapitalism, philanthropy for social justice, poverty, money, United States. 


\section{FILANTROCAPITALISMO}

\section{VERSUS FILANTROPÍA PARA LA JUSTICIA SOCIAL: UN DEBATE \\ NORTEAMERICANO SOBRE CÓMO LIDIAR CON LA POBREZA}

\section{Resumen}

El objetivo de este trabajo es analizar la filantropía estadounidense como una práctica mediante la cual los ricos retribuyen parte de la riqueza que han podido acumular, así como un mecanismo para atenuar la pobreza de los menos exitosos. Se analizan dos formas de filantropía y sus supuestos: el filantrocapitalismo y la filantropía para la justicia social. En ambos casos, se presenta el material analizado en una investigación realizada en los Estados Unidos con representantes de estas dos vertientes. La filantropía se discute a la luz del don, del interés y desinterés en las prácticas sociales y de la obligación moral. Palabras clave: filantropia, filantrocapitalismo, filantropía para la justicia social, pobreza, dinero, Estados Unidos. 